\title{
ASONANSI DALAM CERPEN “UGD” KARYA DJENAR MAESA AYU
}

\author{
Afsun Aulia Nirmala \\ Program Studi Pendidikan Bahasa dan Sastra Indonesia. Universitas Pancasakti Tegal. Jalan \\ Halmahera Km. 1 Kota Tegal, Jawa Tengah, Indonesia
}

Email: gendhissastra@yahoo.com. Telp:085640047679.

\begin{abstract}
ABSTRAK
Penelitian yang membahas mengenai asonansi bisa dikaitkan dengan sastra termasuk cerpen. Cerpen "UGD” karya Djenar Maesa Ayu adalah sebuah karya yang memuat beberapa keindahan bahasa di dalamnya. Djenar mampu meramu bahasa menjadi kalimat yang indah. Dengan demikian penelitian ini diharapkan mampu menganalisis gaya bahasa asonansi di dalam cerpen "UGD" tersebut. Asonansi adalah pengulangan suara vokal untuk membuat rima internal dalam frasa atau kalimat, dan bersama-sama dengan aliterasi dan konsonansi berfungsi sebagai salah satu blok bangunan sajak. Asonansitidak harus sajak; identitas yang tergantung hanya pada urutan vokal dan suara konsonan. Dengan demikian, asonansi adalah kemiripan dari unit yang umumnya kurang dari suku kata. Asonansi lebih sering terjadi pada sajak daripada dalam bentuk prosa Metode penelitian ini adalah deskriptif kualitatif dengan metode simak dan catat. Hasil penelitian ini adalah memjabarkan asonansi dalan cerpen UGD karya Djenar Maesa Ayu.
\end{abstract}

\section{ABSTRACT}

The research that discusses about assonance can be related to literature including short stories. The "UGD" short story by Djenar Maesa Ayu is a work that contains some of the beauty of the language in it. Djenar is able to concoct language into a beautiful sentence. Thus this research is expected to be able to analyze the style of asonance in the "ER" short story. Asonansi is a vowel sound repetition to make internal rhymes in phrases or sentences, and together with alliteration and consonance function as one of the rhyme building blocks. Asonans do not have to rhyme; identity that depends only on the vowel and consonant sounds. Thus, asonance is the resemblance of units which are generally less than syllables. The method of this research is descriptive qualitative with the method of note and note. The results of this study were to describe the asonance in the ER short story by Djenar Maesa Ayu. 


\section{PENDAHULUAN}

Cerpen merupakan salah satu bagian dari karya sastra yang banyak dinikmati oleh masyarakat Indonesia. Selain ringkas dan simpel untuk dibaca, cerpen merupakan sebuah karya yang sarat makna dan penuh dengan gaya bahasa yang menarik perhatian para pembaca. Gaya bahasa inilah yang mendorong para penulis cerpen mengembangkan tulisannya sehingga dapat dengan mudah mencari inspirasi kata dan kalimat selanjutnya.

Selain memiliki keindahan dalam gaya bahasa, sastra merupakan hal yang bisa dijadikan sebagai acuan kehidupan kita sehari-hari. Cerpen merupakan cerminan kehidupan sehari-hari manusia. Sepenggal kisah hidup manusia yang tertuang dalam sebuah karya cerita pendek. Cerpen adalah bacaan sekali duduk yang menyenangkan.

Karena itu bahasa yang ada di dalam cerpen bisa kita jadikan sebuah penelitian khususnya penelitian mengenai gaya bahasa dalam sastra. Salah satu gaya bahasa yang ada di dalam kajian bahasa dan sastra adalah asonansi. Asonansi adalah majas atau gaya bahasa yang dibuat dengan mengulang huruf vokal atau konsonan kata pertama pada kata berikutnya. Secara bahasa, pengertian majas asonansi memang cukup sulit dijelaskan. Akan tetapi rasanya menjadi sangat mudah jika Anda memperhatikan contoh majas asonansi yang telah kami buat dalam penggalan puisi berikut ini. Segala ada, menekan dada Mati api, di dalam hati Harum sekuntum, bunga rahasia Hitam kelam merajam malam. Dari puisi di atas, huruf-huruf pada akhir kata pertama diulang-ulang pada artikel berikutnya.

Oleh karena itu penelitian yang membahas mengenai asonansi bisa dikaitkan dengan sastra termasuk cerpen. Cerpen "UGD" karya Djenar Maesa Ayu adalah sebuah karya yang memuat beberapa keindahan bahasa di dalamnya. Djenar mampu meramu bahasa menjadi kalimat yang indah. Dengan demikian penelitian ini diharapkan mampu menganalisis gaya bahasa asonansi di dalam cerpen "UGD" tersebut.

Asonansi merupakan bagian dari gaya bahasa. Pengertian gaya bahasa menurut Aminuddin (1995: 5) mengemukakan bahwa style atau gaya bahasa merupakan cara yang digunakan oleh pengarang dalam 
memeparkan gagasannya sesuai dengan tujuan dan efek yang ingin dicapai. Edangkan menurut Tarigan ( 1985: 5) gaya bahasa merupakan bentuk retorik, yaitu penggunaan kata-kata dalam berbicara dan menulis untuk meyakinkan atau mempengaruhi penyimak dan pembaca.

Berbeda lagi dengan pengertian gaya bahasa menurut Harimurti (dalam Pradopo, 1993: 265) adalah pemanfaatan ataskekayaan bahasa seseorang dalam bertutur atau menulis, lebih khusus adalah pemakaian ragam bahasa tertentu untuk memperoleh efek tertentu. Efek yang dimaksud dalam hal ini adalah efek estetis yang menghasilkan nilai seni. Sedangkan Achmadi (1988: 155-156) adalah kualitas visi, pandangan seseorang, karena merefleksikan cara seorang pengarang memilih dan meletakkan kata-kata dan kalimat-kalimat dalam mekanik karangannya. Gaya bahasa menciptakan keadaan perasaan hati tertentu, misalnya kesan baik ataupun buruk, senang, tidak enak dan sebagainya yang diterima pikiran dan perasaan karena pelukisan tempat, benda-benda, suatu keadaan atau kondisi tertentu.
Jadi bisa disintesiskan bahwa gaya bahasa adalah cara penulis mengekspresikan gaya bahanasnya untuk menarik, meyakinkan dan memengaruhi pembaca. Gaya bahasa juga berhubungan dengan nilai estetis yang erat kaitannya dengan peasaan seseorang. Baik senang, sedih, baik atau buruk dan melukiskan kondisi tertentu.

\section{Asonansi adalah pengulangan}

\section{suara vokal untuk membuat rima}

\section{internal dalam frasa atau kalimat,} dan bersama-sama dengan aliterasi dan konsonansi berfungsi sebagai salah satu blok bangunan sajak. Asonansitidak harus sajak; identitas yang tergantung hanya pada urutan vokal dan suara konsonan. Dengan demikian, asonansi adalah kemiripan dari unit yang umumnya kurang dari suku kata. Asonansi lebih sering terjadi pada sajak daripada dalam bentuk prosa.(Wikipedia).

\section{METODE}

\section{Jenis Penelitian}

Penelitian yang digunakan dalam penelitian ini adalah berjenis deskripsi kulaitatif. Menurut Azwar (2013,5) penelitian dengan pendekatan kualitatif menekankan pada hasil analisisnya pada proses penyimpulan dengan pola 
deduktif. dan induktif, pendekatan ini juga lebih menekankan pada dinamika hubungan antarfenomena yang diamati, dengan menggunakan logika ilmiah.

\section{Waktu Penelitian}

Waktu pelaksanaan penelitian ini adalah pada bulan Juli 2018 s.d. Agustus 2019.

\section{Target/Subjek Penelitian}

Subjek dalam penelitian ini adalah sebuah cerpen yang berjudul UGD karya Djenar Maesa Ayu.

\section{Prosedur}

Penelitian yang dilakukan dengan menggunakan metode simak catat. Peneliti membaca cerpen yang telah diplih kemudian dibaca dan dicatat asonansi yang ada di dalam cerepn tersebut.

\section{Data, Instrumen, dan Teknik}

\section{Pengumpulan Data}

Sumber data dalam penelitian ini adalah teks yang terdapat di dalam cerpen UGD karya Djenar Maesa Ayu. Teknik pengumpulan data yang digunakan dalam penelitian ini adalah metode simak dengan metode catat. Data penelitian yang didapat berupa kesalahan penggunaan kohesi gramatikal yang terdapat dalam teks.

\section{Teknik Analisis Data}

Data yang diperoleh kemudian dilakukan analisis berdasarkan analisis isi dengan melakukan identifikasi dan dirduksi. Adapun penyajian hasil analisis data ditempuh dengan penyajian informal, yaitu penyajian dengan kata-kata biasa.

\section{HASIL DAN PEMBAHASAN}

\section{Asonansi memberat- surat.}

Terdapat pada kalimat " Sumali menunggu di sudut kafe dengan pelupuk mata yang semakin memberat sambil menggenggam secarik surat" ( UGD, 2012:1).

\section{Asonansi merinding-jam dinding.}

Terdapat pada kalimat "malam merinding kala berdentang dua belas kali jam dinding" ( UGD, 2012:2).

Asonansi merinding-kering. Bulu kuduk Nayla merinding sambil menggenggam kaleng yang isinya telah kering.

Asonansi berdering-gasing. Dihiraukannya bunyi telepn yang tak berhenti berdering. Waktu berputar di kepalanya seperti gasing.

Asonansi

persendiannya-

mengingatkannya. Sumali merentangkan persendiannya. Jika dulu waktu dua jam terlewat tanpa terasa, kini otot-otot tuanyalah yang kerap terjaga dan mengingatkannya. 
Asonansi

bicara-penderitaannya.

Apalagi jika tak ada lawan bicara.

Sengatan nyamuk yang membabi buta pun semakin menambah penderitaannya.

Asonansi besar-keluar. Kentaannya adalah salah besar. Dua jam dirinya terperangkap kemacetan, di dalam jalan bebas hambatan yang masih berjarak jauh dari pintu gerbang keluar.

Asonansi penuh dalam satu paragraf:

“ Jantung Sumali semakin terasa berdebar. Namun ia masih mencoba bersabar. Pandangannya pu berpendar-pendar. Maka dihirupnya napas dalam-dalam demi mendapat udara segar. Namun tindakannya tidaklah membantu benar. Karena Sumali menjadi sadar penantiannya hanyalah sebuah kelakar. Seharussnya sudah sejak awal Sumali tahujika dirinya kemugkinan besar hanya dipandang layaknya ulat tua yang rindu menyantap daun segar." (UGD, 2012: 3).

“Jantung Nayla semakin terasa berdebar. Kini ia sudah benar-benar hilang sabar. Tak ada tanda-tanda kemacetan akan buyar. Ia pun mulai membuka kaca jendela mobilnya
Asonansi gusar-lancar. Nayla menatap arloji di tangan kanannya dengan gusar, sambil mengutuk dirinya sendiri yang sempat berpikir arus lalu lintas akan lancar,

lebar-lebar. Demi mendapat udara segar. Namun pertama kali tertangkap telinganya adalah suara klakson dari banyak mobil yang terdengar sangat sangar. Suara yang tak biasanya ia hiraukan jika di sebelahnya duduk seorang dengan rimbun senyum snantiasa menebar. Membuat sirna sudah jurang usia di depan mereka yang terbentang lebar." (UGD, 2012: 3).

\section{SIMPULAN}

Berdasarkan hasil penelitian tersebut maka dapat disimpulkan bahwa asonansi yang terdapat dalam karya sastra bertujuan untuk menciptakan bahasa yang penuh dengan keindaha. Bahasa yang penuh dengan style inilah yang diguanakan untum menarik perhatian pembaca. Dalam cerpen UGD karya Djenar Maesa Ayu ini ditemukan hampir dalam setiap paragraf memuat asoansi di dalamnya.

\section{DAFTAR PUSTAKA}

Aminuddin. 1995. Stilistika : Pengantar Memahami Bahasa dalam Karya 
Sastra. Semarang $\quad: \quad$ IKIP

Semarang Press.

Pradopo, Rahmat Djoko. 1995. Beberapa

Teori Sastra, Metode, dan.

Penggunaannya. Yogyakarta :

Pustaka Pelajar.

Tarigan, Henry Guntur. 1985.

Pengajaran Gaya Bahasa.

Bandung: Penerbit Angkasa.

Ayu, Djenar Maesa. 2012. Kumcerepen T (w)ITIT. Jakarta: Gramedia Pustaka Utama.
6. PROFIL SINGKAT

Afsun Aulia Nirmala lahir di Brebes pada tanggal 25 Februari 1986. Meluluskan pendidikan S2 di Universitas sebelas Maret pada tahu 2010. Dan aktif mengajar di Prodi Pendidikan Bahasa dan sastra Indonesia UPS Tegal dari tahun 2010 hingga sekarang. 